\title{
8
}

\section{im

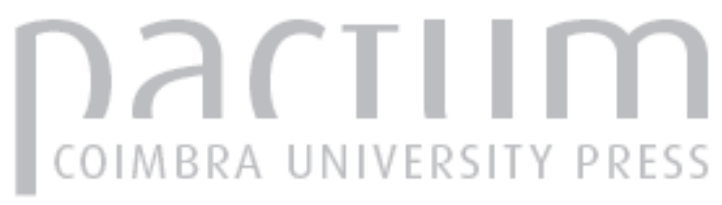

\section{Licença para (não) reproduzir: os direitos sexuais e reprodutivos no espaço mediático}

\author{
Autor(es): $\quad$ Silveirinha, Maria João
}

Publicado por: Faculdade de Letras da Universidade de Coimbra, Instituto de Estudos

URL

persistente: Filosóficos

DOI: $\quad$ DOI:http://dx.doi.org/10.14195/0872-0851_34_6

Accessed : $\quad$ 26-Apr-2023 11:12:49

A navegação consulta e descarregamento dos títulos inseridos nas Bibliotecas Digitais UC Digitalis, UC Pombalina e UC Impactum, pressupõem a aceitação plena e sem reservas dos Termos e Condições de Uso destas Bibliotecas Digitais, disponíveis em https://digitalis.uc.pt/pt-pt/termos.

Conforme exposto nos referidos Termos e Condições de Uso, o descarregamento de títulos de acesso restrito requer uma licença válida de autorização devendo o utilizador aceder ao(s) documento(s) a partir de um endereço de IP da instituição detentora da supramencionada licença.

Ao utilizador é apenas permitido o descarregamento para uso pessoal, pelo que o emprego do(s) título(s) descarregado(s) para outro fim, designadamente comercial, carece de autorização do respetivo autor ou editor da obra.

Na medida em que todas as obras da UC Digitalis se encontram protegidas pelo Código do Direito de Autor e Direitos Conexos e demais legislação aplicável, toda a cópia, parcial ou total, deste documento, nos casos em que é legalmente admitida, deverá conter ou fazer-se acompanhar por este aviso.

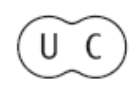




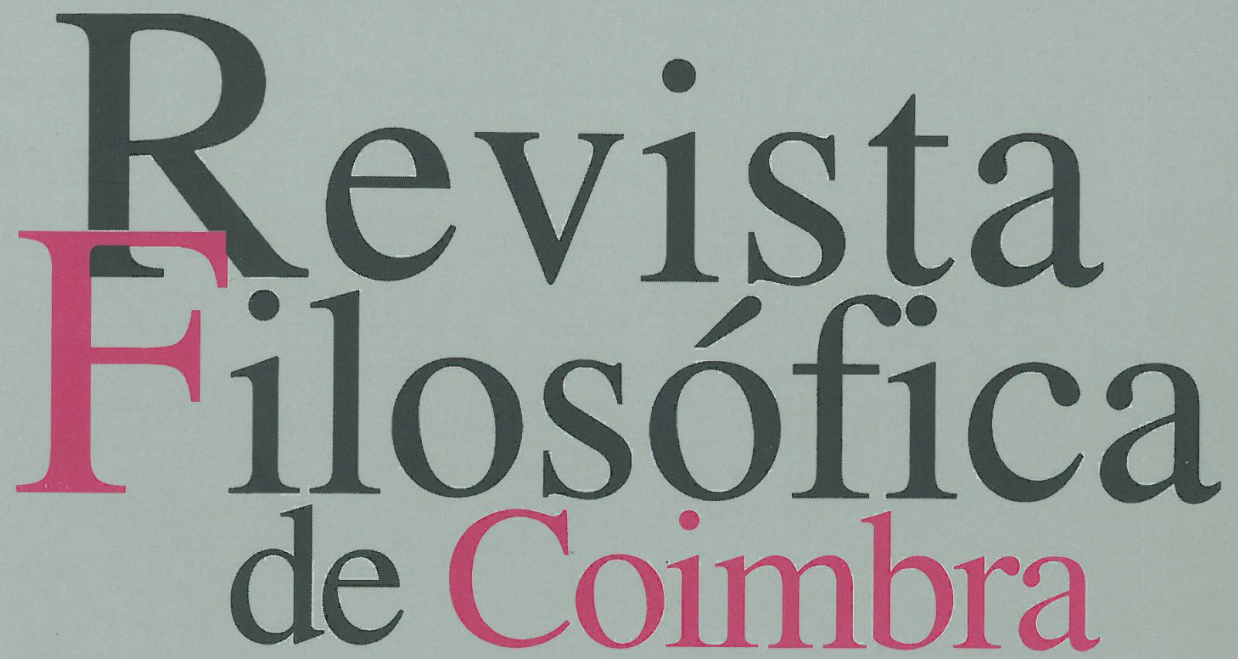

vol.17 | n.34 | 2008

José Reis

Manuel Moreira da Silva Helder Gomes

Filipe P. S. M. Menezes Edmundo Balsemão Maria João Silveirinha Luís António Umbelino Cláudio Alexandre S. Carvalho Armindo dos Santos Ana Isabel Boura Regina Queiroz Dulce Morgado Neves 


\section{LICENÇA PARA (NÃO) REPRODUZIR: OS DIREITOS SEXUAIS E REPRODUTIVOS NO ESPAÇO MEDIÁTICO}

MARIA JOÃO SILVEIRINHA

(Instituto de Estudos Jornalísticos - Faculdade de Letras - Universidade de Coimbra)

\section{Introdução}

A fertilização in vitro fez manchetes em 1978 quando nasceu Louise Brown, o primeiro "bebé-proveta". Em Portugal, a primeira criança a ser concebida por este procedimento nasceria em 1986, com destaque na imprensa nacional. Vinte anos depois, era promulgada a primeira lei sobre Procriação Medicamente Assistida, também esta com destaques na imprensa. Algum tempo antes, um novo referendo sobre o aborto colocara também as questões da saúde sexual e reprodutiva das mulheres na agenda política e dos media. Num relativo curto espaço de tempo, as agendas feminista, social, política e dos media cruzavam-se, assim, em torno de questões relacionadas com a saúde sexual e reprodutiva das mulheres. O que neste texto nos propomos fazer é uma reflexão que dê conta não só das especificidades de cada uma destas agendas, como, e sobretudo, da configuração de sentido que o seu cruzamento no espaço público produz.

Temas como o aborto, o controlo de nascimento, o planeamento familiar e as tecnologias reprodutivas são hoje discutidos e regulados por instâncias nacionais e internacionais, mas a sua presença pública deve-se à vanguarda do trabalho feminista que, desde cedo, exigiu a autonomia da acção das mulheres no que toca à reprodução. Em sistemas patriarcais, onde as questões da reprodução eram factores de opressão ou diminuição das mulheres, as feministas desencadearam um trabalho de exigência de reconhecimento destas problemáticas que, nas últimas duas décadas, seria finalmente materializado em documentos internacionais. Nesse sentido, o Plano de Acção adoptado a partir da Conferência Internacional sobre População e Desenvolvimento (Cairo, 1994) define a saúde reprodutiva como "um estado completo de bem-estar físico, mental, e social (...) A 
saúde reprodutiva implica (...) que as pessoas são capazes de ter uma vida sexual segura e satisfatória e que possuem a capacidade de se reproduzir e a liberdade para decidir se, quando e com que frequência devem fazê-lo" 1 . Também a Declaração de Pequim e a respectiva Plataforma da Acção (Quarta Conferência Mundial sobre as Mulheres, 1995) repetem esta definição, afirmando no seu $96^{\circ}$ parágrafo que "os direitos humanos das mulheres incluem o seu direito de controlar e decidir livremente e com responsabilidade em matérias relacionadas com a sua sexualidade, incluindo a saúde sexual e reprodutiva, sem coerção, discriminação e violência" " Este reconhecimento dos direitos reprodutivos das mulheres tem sido, no entanto, difícil de implementar e é matéria de uma luta contínua, tanto a níveis nacionais como internacionais ${ }^{3}$. Uma parte desta luta é precisamente a estabilização do significado social e político destes direitos que deve recolher suficiente consenso para que as leis que sobre eles versam tenham a necessária legitimidade.

Portugal não é excepção ao trabalho de regulação dos direitos sexuais e reprodutivos que se incluem no espectro das questões da saúde até porque, como Graça Carapinheiro (2006) faz notar, esta sempre foi fortemente impulsionada por orientações internacionais. Por isso, nos

1 Plataforma de Acção da Conferência Internacional sobre População e Desenvolvimento, adoptada a 18 Out. 1994, U.N. GAOR, Cap.. VII, § 7.2, U.N. Doc. A/CONF.171/13 (1994).

2 Relatório da Quarta Conferência Mundial sobre as Mulheres, Declaração de Pequim e Plataforma de Acção, adoptada a 17 Out., U.N. GAOR, 50 a Sess., §§ 94-96, U.N. Doc. A/CONF. 177/20 (1995); ver também Relatório do Comité para a Eliminação da Discriminação contra as Mulheres na sua $20^{a}$ sessão: Recomendação 24, U.N. GAOR, 54th Sess., Supp. No. 38, Pt. I, § 23, U.N. Doc. A/54/38/Rev.1, cap. I (1999).

${ }^{3}$ Rebecca J. Cook \& Mahmoud F. Fathalla, “Advancing Reproductive Rights Beyond Cairo And Beijing", In Women And International Human Rights Law Vol. 3, At 73-90 (Kelly D. Askin \& Dorean M. Koenig Eds., 1999); Maja Kirilova Eriksson, "Abortion And Reproductive Health: Making International Law More Responsive To Women's Needs", In Id. At 71; Rishona Fleishman, The Battle Against Reproductive Rights: The Impact Of The Catholic Church On Abortion Law In Both International And Domestic Arenas, 14 Emory Int'1 L. Rev. 277 (2000); Doris Elisabeth Buss, Going Global: Feminist Theory, International Law, And The Public/Private Divide, In Challenging The Public/ Private Divide: Feminism, Law, And Public Policy 360 (Susan B. Boyd Ed., 1997); Catharine A. MacKinnon, Feminism Unmodified: Discourses on Life and Law (Cambridge, Mass., 1987); Mary Ann Glendon, Abortion And Divorce In Western Law (1987); Drucilla Cornell, The Imaginary Domain: Abortion, Pornography \& Sexual Harassment 31-37 (1995). 
últimos anos, com avanços e recuos, o país tem produzido legislação sobre matérias como o aborto e a procriação medicamente assistida.

É, pois, no quadro das lutas simbólicas subjacentes ao significado do que os direitos sexuais e reprodutivos implicam que estes temas têm aflorado o espaço mediático. Para além do referendo sobre o aborto, que agitou de um modo muito intenso e particular o espaço público nacional, os acontecimentos ligados à genética em geral e a recente legislação sobre Procriação Medicamente Assistida produziram intervenções no que Habermas chama uma "esfera pública em descanso" mas que, no plano ideal, deve resultar de uma influência das deliberações públicas quotidianas sobre os discursos formais, institucionalizados e constitucionais (Habermas, 1996, p. 379).

Numa tentativa de compreensão da dimensão pública de uma matéria particularmente relevante para a igualdade de género, é o tema da Procriação Medicamente Assistida e das lutas simbólicas por ela desencadeadas que nos ocupará neste texto. $\mathrm{Na}$ verdade, o desenvolvimento técnico-científico na área da saúde reprodutiva não tem uma leitura social e política unívoca. Fruto da investigação biomédica que tem tornado o parto e o aborto mais seguros, a contracepção e tratamento da infertilidade mais eficaz e a medicina reprodutiva mais sofisticada, o tema, ao projectar-se para além do estrito domínio científico, encontra defensores e opositores que, em confronto e em conjunção com operadores de sentido como os introduzidos pelos media, produzem uma visibilidade pública particular que simultaneamente traduz e constrói visões de nós mesmas/ os e da nossa vida em comum.

$\mathrm{Na}$ verdade, os direitos reprodutivos são centrais à concepção da nossa individualidade e penetram fundo na nossa vida quotidiana pessoal e colectiva. Em particular, tocam as áreas íntimas da vida das mulheres e dos seus estilos de família e interceptam quase todas as suas esferas de acção e de pensamento - desde a autonomia pessoal, à ética pessoal e profissional, às crenças religiosas. Por esta razão, são uma matéria que alimenta dilemas e disputas públicas, abarcando no mesmo espaço de interacção um grande leque de actores sociais, como médicos, leigos, políticos, sociedade civil, empresas e especialistas. É a esse espaço, que encontra nos media contemporâneos o seu principal elemento de circulação, que, entendido no seu sentido normativo, chamamos espaço público.

Tendo adquirido, apenas nas últimas décadas, visibilidade pública, o tema da saúde sexual e reprodutiva, como já referimos, constitui-se como tendo enorme relevância para as mulheres, tocando não só a sua esfera íntima e privada como o seu lugar na vida pública. Na verdade, se uma mulher não tiver o direito de controlar a sua própria vida reprodutiva quando engravidar, quando manter e quando terminar uma gravidez ou 
como ter ou não filhos de um modo autónomo ou partilhado - como pode ter outros direitos? Por exemplo, como ficam os direitos relativos à sua carreira, à sua vida afectiva? Se não lhe for permitido fazer escolhas autónomas em termos de contracepção e aborto, decisões que se ligam à integridade do seu próprio corpo, é questionável que, noutras áreas da sua vida, possa agir de modo independente. Isto não significa a precedência da questão reprodutiva, mas ilustra a sua profunda ligação a outros direitos políticos.

Estamos hoje, portanto, longe do tempo em que a sexualidade e a reprodução eram temas estritamente privados, ou mais do que isso, eram o mais privado dos temas. Com a sua publicitação e transformação em matérias de cidadania vêm também novas questões: o que acontece aos direitos reprodutivos quando projectados no espaço público? De que modo este nos devolve a subjectividade e o político associados a estas questões? Que definições e que poderes de criar essas mesmas definições estão em causa quando os direitos sexuais e reprodutivos se transformam em matéria de discussão pública? O que constitui o espaço público neste domínio? Nestas interrogações, são diversos os domínios a convocar.

Em primeiro lugar, é a identidade de género que está em causa: o processo da reprodução é central à compreensão da diferença sexual, no sentido em que a capacidade de conceber e dar à luz é geralmente considerada a característica que distingue a mulher e o homem. $\mathrm{Na}$ verdade, ainda que a antropologia dê a conhecer outros modelos, "a compreensão cultural ocidental dominante [da reprodução] é a de matrigénese, segundo a qual a mulher dá a vida a uma criança. Também a relação de mãe-criança é conceptualizada como um produto da natureza - instinto maternal - ao passo que não há conceito correspondente da paternidade como um fenómeno natural" (Lie, 2002, p. 384). Esta ligação à natureza da mulher através da maternidade é precisamente o que é separado com o advento da ciência, das Novas Tecnologias Reprodutivas $(\mathrm{NTR})^{4}$ e das narrativas que as acompanham. Perante elas, as sociedades são obrigadas a repensar as relações de parentesco e as bases da sociedade em termos das identidades que lhe dão forma: o que é a família, o que é o parentesco, o género e o que significa ser mãe ou pai. Afinal, como referia em título um jornal nacional "mãe não há só uma".

Por outro lado, associados às NTR e à sua projecção no espaço público, processos como a fecundação in vitro permitem vislumbrar um processo mais vasto de medicalização e de tecnologização do corpo que

${ }^{4}$ Por uma questão de economia de espaço daqui em diante será utilizada a abreviatura NTR para nos referirmos às Novas Tecnologias Reprodutivas. 
criou novos sujeitos de intervenção médica, que também impulsionaram a reconsideração dos nossos corpos. Na verdade, na medida em que se constituem como poderosos instrumentos de visualização e de controlo dos fetos e das mulheres que os geram, muitas das tecnologias associadas à maternidade afectam as concepções de nós mesmas como sujeitos desse controlo. A proeminência da medicalização e da tecnologização do corpo gerou também todo um discurso em torno da infertilidade e da necessidade da reprodução biológica dos casais que importa estudar.

Em terceiro lugar, quando as NTR são projectadas no espaço público fazem-no necessariamente no quadro de uma linguagem própria que é a dos media. O lugar dos meios de comunicação social na constituição do espaço público não pode, com efeito, ser ignorado: antes de mais, porque por eles passa a visibilidade e opacidade dos temas em questão; por outro lado, porque os media recontextualizam - na linguagem que lhes é própria e que é devedora do seu entendimento autónomo de como essa recontextualização se deve fazer - as informações parcelares dos diferentes actores envolvidos, projectando para o espaço público as exigências culturais e normativas que lhes estão associadas. Assim, quando as notícias e as discussões nos media abordam as novas tecnologias reprodutivas - seja através da narrativização de histórias pessoais, das notícias de ciência ou das discussões públicas das normas que as regem - vemos em jogo questões de legitimidade identitária, da face pública do poder da medicina sobre os nossos corpos e da própria compreensão pública da ciência.

Por fim, está em causa a constituição do próprio espaço público: o que ele significa quando organizado em torno das NTR e o que coloca em jogo em termos da nossa vida em comum.

No que se segue, procuraremos, então, pensar as Novas Tecnologias Reprodutivas mediante estes quatro nódulos que inevitavelmente se cruzam: as novas tecnologias reprodutivas e as identidades das mulheres; a medicalização e a tecnologização do corpo e da reprodução; as questões da ciência no espaço mediático; e as questões do espaço público como lugar de distribuição e reconhecimento.

\section{As Novas Tecnologias Reprodutivas e as identidades das mulheres}

Como já dissemos, nas sociedades Ocidentais, o direito à liberdade de decidir, de planear e de ter um maior controlo sobre a gravidez foi conseguido a partir do direito à saúde reprodutiva reconhecido depois da Conferência Mundial de Pequim sobre as Mulheres. Mas, particularmente desde os anos 1980, a posição feminista sobre a importância das diferenças sexuais viria a desenvolver-se sob diferentes influências, 
dividindo-se na sua posição face ao significado da biologia, da maternidade e das novas tecnologias reprodutivas.

No tocante a estas últimas, e num inevitável quadro de abordagem que marca, por exemplo, as questões do aborto como sendo questões de "escolha", todas as feministas abordam as NTR a partir da convicção de que o controlo próprio da reprodução das mulheres é uma capacidade importante. Nem todas as feministas, no entanto, partilham do significado que se pode atribuir a esse controlo. Neste ponto, como em muitos outros, o feminismo não é, como nunca foi, um movimento uniforme.

Para uma boa parte das teóricas agrupadas sob o "feminismo da igualdade", as novas tecnologias reprodutivas significam, entre outras possibilidades, a capacidade de deslocar ovócitos ou embriões do corpo da mulher criando, desse modo, opções que, na linha das feministas da segunda vaga, contêm um forte potencial de emancipação. Já em 1949 Simone de Beauvoir descreveu apaixonadamente a escravização da mulher ao que ela chamou as "forças exteriores" das suas biologias reprodutivas:

[A mulher] é entre todas as fêmeas de mamíferos a que se acha mais profundamente alienada e a que recusa mais violentamente esta alienação; em nenhuma a escravização do organismo à função reprodutora é mais imperiosa nem mais dificilmente aceite: crises da puberdade e da menopausa, 'maldição' mensal, gravidez prolongada não raro difícil, parto doloroso e por vezes perigoso, doenças, acidentes, são características da fêmea humana (de Beauvoir, 1975, p. 61).

Ao contrário dos homens, cujos sistemas endócrinos não criam crises significativas, uma mulher deve esforçar-se por manter a sua individualidade e resistir à sua "escravização" perante as exigências da reprodução biológica que não têm fisiologicamente nenhum benefício para ela (de Beauvoir 1975, p. 54-61, Roberts, 2007). O papel subordinado da mulher não pode, no entanto, ser explicado pela biologia, mas por um processo social e cultural.

Firestone é a mais famosa e uma das primeiras proponentes das NTR como libertadoras "da tirania da reprodução" (1970, p. 193). Em The Dialectic of Sex assinala que a desigualdade inicial entre mulheres e homens radica numa fonte concreta e material: o corpo. Por isso, se a raiz da opressão feminina é biológica, só uma revolução na biologia pode mudar a posição social das mulheres. Em última análise, a causa da subjugação da mulher é a sua função sexual/reprodutiva e as diferenças biológicas que a separam dos homens. O simples facto de as mulheres darem à luz e criarem os filhos mostra como, ao contrário dos homens, estão fundamentalmente ligadas e dependentes de outros. Este dese- 
quilíbrio de poder repercute-se depois no desequilíbrio entre crianças e adultos e são esses desequilíbrios biológicos que marcaram desde sempre todas as sociedades. Para serem verdadeiramente autónomas, as mulheres precisam de se libertar da carga associada à produção de filhos com os seus próprios corpos, uma carga que as limita e degrada fisicamente. No entanto, para Firestone, a biologia não precisa de ser uma prisão sem escape. Se a raiz da opressão da mulher está na anatomo-fisiologia, a solução deve estar na tecnologia, que permitirá aumentar o controlo da concepção e da gestação fora do útero. Afirmando aberta e claramente que "a gravidez é bárbara" (Firestone, 1970, p. 188), Firestone defende que os desenvolvimentos tecnológicos na reprodução poderiam acabar com a tirania da família biológica. A gestação extra-uterina constitui-se, assim, como uma estratégia de libertação, pondo fim à imposição da maternidade biológica.

Toda uma linha de feminismo, no entanto, não seguiria o impulso de Firestone, tendendo antes a rejeitar as NTR. Mais do que ver na reprodução artificial um meio de eliminar a opressão dentro de um sistema patriarcal, outras feministas viram no facto de só as mulheres poderem reproduzir uma fonte de poder que elas deveriam controlar, em vez de colocarem nas mãos dos homens a oportunidade de intervir nos seus corpos. Como explica Lam (2004, p. 3), nesta linha de pensamento:

A tecno-ciência (...) é uma tecnologia de apropriação do nascimento projectada e usada pelos homens para superar a sua alienação reprodutiva da natureza. Enfim [com esta tecnologia] os homens podem reclamar os poderes da reprodução para si manipulando os processos reprodutivos femininos e recriando-os fora do corpo feminino humano.

Assim, começando por uma perspectiva ética, a partir de uma reacção negativa ao foco nos direitos individuais, o feminismo relacional desenvolveu uma posição crítica das NTR, defendendo antes uma ética do cuidado que permitisse desenvolver um sistema de interligação e um sentido de responsabilidade mútua. Partindo de Carol Gilligan, que investigou as diferenças entre rapazes e raparigas no seu desenvolvimento moral, encontrando processos morais analíticos distintos, avançou-se esta ideia: os processos reprodutivos "naturais" da mulher são uma fonte de identidade feminina, um bastião de poder e solidariedade da mulher que é única e exclusivamente sua.

Desde muito cedo o feminismo radical seria pensado também em termos fortemente maternalistas. Para Adrienne Rich (1976) em particular, o patriarcado alienou as mulheres do potencial da sua capacidade procriativa, distorcendo a maternidade para uma instituição opressora. 
A maternidade como instituição era pouco recomendável mas, livre das distorções que lhe haviam sido impostas, podia ser um lugar de auto-actualização feminina, permitindo às mulheres recuperar o sentido próprio dos seus corpos. A maternidade continha um potencial corporal imanente e esse potencial - mais do que produção física de crianças - podia ser fonte de autonomia e de sentido próprio. $\mathrm{Na}$ verdade, a fonte do problema da desigualdade de género não estaria na biologia, mas no modo como esta foi institucionalizada pelo patriarcado, separando a mente do corpo e distorcendo a experiência feminina. É nesta separação, argumentou Rich, que reside a capacidade do patriarcado sobreviver. Se as mulheres conseguissem reclamar a maternidade como uma experiência, mais do que como uma instituição, poderiam ser mais autónomas nas suas vidas, ligarse umas às outras e em última análise alterar o curso da história.

Também a natureza historicamente opressiva dos processos médicos e tecnológicos sobre os corpos das mulheres, em especial na utilização das Novas Tecnologias Reprodutivas, foi igualmente desde cedo uma das principais preocupações do feminismo radical. Patricia Spallone descreveu a tecnologia reprodutiva como mais um meio de estender o controlo masculino da reprodução para o meio da concepção. Não se trata, na verdade, de dar às mulheres uma outra "escolha" reprodutiva: os interesses em causa são apenas as "várias necessidades e os desejos dos cientistas médicos, cientistas sociais, e o Estado para avançar o 'progresso' tecnológico e ajudar objectivos de controlo demográfico" (Spallone, 1989, p. 2). A autora descreve o poder das mulheres a partir da experiência colectiva, procurando restabelecer a capacidade de acção das mulheres por oposição a uma excessiva confiança na medicina altamente tecnologizada. Uma perspectiva da diferença sobre as NTR recusa-as como instrumentos masculinos e coloca a tónica na necessidade de serem as mulheres a assumir o controlo dos seus corpos, como acontece com a sua decisão de abortar. Na mesma linha de pensamento, diz Robyn Rowland:

$\mathrm{O}$ que as feministas na verdade querem dizer 'com o direito de uma mulher de escolher' é 'o direito de uma mulher de controlar'. As mulheres reclamam o direito à integridade do seu corpo, à autonomia e ao respeito como seres humanos morais capazes de tomar decisões difíceis nesta área. As mulheres precisam do acesso ao aborto para controlar as suas vidas num mundo menos do que perfeito. Temos de colocar a mesma questão relativamente à tecnologia reprodutiva: elas aumentam necessariamente o controlo das mulheres sobre as suas vidas? (Rowland, 1992, p. 285).

Para Rowland, a resposta é negativa. A fertilização in vitro não parte das causas conhecidas e que podem ser sujeitas a prevenção, mas da 
premissa da causa como um problema médico. Por detrás, está todo um aparelho justificativo da super-ovulação, a colheita de ovócitos e a fertilização nos laboratórios que não são mais do que processos levados a cabo por uma profissão médica masculina para controlar a fertilidade. $\mathrm{E}$, enquanto a tecnologia reprodutiva for controlada pelos homens, não será usada para dar poder às mulheres, mas para consolidar o poder masculino (Corea, 1985). Elaine Denny resume assim a perspectiva feminista radical:

Um dos temas principais do feminismo radical é o do poder e controlo. A fertilização in vitro é parte de uma tentativa masculina de controlar a sexualidade e fertilidade femininas e precisa de ser colocada dentro deste contexto mais vasto. Embora a fertilização in vitro seja promovida como um tratamento da infertilidade, a ênfase na tecnologia é sobre o controle da capacidade reprodutiva. (...) Na ideologia feminista radical, o desejo das mulheres de terem crianças é alimentado por uma ideologia pro-natalista, explorado por homens ansiosos de dominar a natureza (Denny 1994, p. 70).

Nem todas as mulheres, no entanto, se colocam de um modo tão polarizado face aos benefícios ou perdas de autonomia quando confrontadas com as NTR. Na bibliografia é ainda possível encontrar um conjunto de trabalhos que procura indagar empiricamente as experiências individuais das mulheres, dando conta da sua grande diversidade e da impossibilidade de as generalizar. Carla Lam (2004) chama a estes trabalhos "ambivalentes":

Ao recusar as experiências das mulheres como falsa consciência, o feminismo radical nega-lhes precisamente o mesmo que o patriarcado lhes nega (...) do mesmo modo como o patriarcado culpa as mulheres pelos problemas que emanam de fora da família, mas que se manifestam no interior da família, também as feministas localizam o pró-natalismo como um problema dos inférteis. Os inférteis são uma manifestação altamente visível da ideologia pró-natalista, mas não são a sua fonte. (Lam, 2004, p.78)

Em qualquer destes casos e seja qual for a perspectiva adoptada, o que parece certo é que os corpos femininos permanecem centrais a questões de poder e de liberdade de uma forma que Beauvoir antecipou com enorme visão. Também a aparente contradição na sua posição - a formação de uma mulher é um processo social/cultural mas as mulheres constantemente lutam contra as forças poderosas da biologia - exprime um dilema que continua hoje dentro da teoria feminista. Até que ponto as mulheres têm posições subordinadas socialmente sob o efeito das suas 
biologias e quais são as possibilidades de modificação contra as "forças" biológicas?

No coração deste dilema, como recorda Roberts (2007), residem significações diferentes de "biologia" e deslizamentos periódicos entre a biologia como ciência e a biologia como corpo material. Seria esse dilema que se traduziria no conhecido debate "sexo/género" e que, depois do trabalho de Beauvoir, respondendo à naturalização das diferenças de género inerentes a esta perspectiva clínica, pedia uma distinção mais clara entre sexo e género. Outras reconheceram as diferenças biológicas entre homens e mulheres, mas argumentaram que o seu significado era social. O sexo e o género não podem ser vistos como separáveis, mas também não se ligam de uma forma inevitável. As ligações entre sexo e género são vividas pelo corpo, mas são sempre "social e historicamente específicas".

A crescente consciência da historicidade da experiência e a constituição performativa dos discursos sobre os nossos próprios corpos contribuiu fortemente para novas perspectivas sobre a identidade feminina, mas agora a partir do corpo vivido e utilizado de formas específicas, representado por e constitutivo de sistemas de sentido e de representação. Este pensamento sobre a construção cultural do corpo colocou, no entanto, novas interrogações sobre a natureza da diferença. Se afirmássemos alguma diferença entre homens e mulheres quanto ao corpo, tal implicaria algum tipo de afirmação biológica e, portanto, um argumento essencialista ou, por outro lado, correríamos o risco de estabelecer um corpo impossivelmente flexível, em que todas as diferenças eram sociais e mutáveis? A investigação e as intervenções políticas das feministas negras e lésbicas tornaram o debate ainda mais complexo. $\mathrm{Na}$ verdade, em causa passou a estar o próprio questionamento da categoria "mulher", motivo de crise na teoria feminista. Se não há nenhum ponto essencial (biológico ou outro) comum entre as mulheres, podem elas ser consideradas um grupo capaz de fazer exigências normativas?

A fortificação e o retrabalhar do termo "género" não facilitaram uma resposta a este dilema, como pode ser visto em particular no trabalho de Judith Butler. Ao pedir ao feminismo que abandone uma pretensão forte de identidade psico-sexual como base de uma teoria e de uma política feminista, o seu trabalho é, na reconsideração da identidade feminina, central. A publicação de Gender Trouble e o seu desenvolvimento nas obras seguintes teve um enorme impacto no estatuto da palavra "género" e na sua relação com o "sexo" e "o corpo". Em causa estava a préexistência dum corpo a-significante sobre o qual se inscreveriam as expressões do género. A história, por definição, produz o apagamento do corpo e, por isso, o corpo não é algo totalmente impresso pela história 
ou pela cultura (patriarcal) - não sendo portanto a construção cultural inescapável que as narrativas feministas de algum modo pressupuseram. Pelo contrário, a identidade de género produz-se por uma sequência de actos performativos. Do mesmo modo, tão-pouco podemos compreender o sexo e o género como os elementos resultantes de uma pré-relação entre eles. Para Butler, nem o sexo nem o género são "naturais": ambos são produzidos como os efeitos das acções repetidas que são culturalmente inteligíveis. Butler opõe-se assim à ordem de relações que se estabelecem num pensamento como aquele que equaciona, por exemplo, que uma fêmea (biológica) se defina por traços femininos e que, numa prática compulsória da heterossexualidade, tenha como objecto de desejo os homens. Um sistema de heterossexualidade pode explicar a formação de identidade sexuais binárias, mas não explica a microdinâmica das identidades psico-sexuais. Na verdade, defende, nem o sexo nem o género são naturais ou uma "substância" e, não sendo o género natural, não há nenhuma relação necessária entre o corpo e o género. O sexo e os corpos sexuais materializam-se pela operação do género, uma operação que é obscurecida. Mas o trabalho de os distinguir - tarefa de que as feministas se ocupam há muito - é infrutífero. Se o género não é algo natural, é o resultado de um conjunto de normas sociais que, mediante palavras, acções, e desejos, produzem e defendem a ficção da coerência heterossexual reprodutiva, provocando a ilusão de que esse é o único modo de ser possível - e não porque o corpo seja algo passivo e dado, mas porque também ele é uma construção reguladora. O sexo é, desde logo e sempre, género, não havendo um corpo natural pré-existente à sua inscrição cultural. O género é produzido dentro de determinados constrangimentos culturais - "matriz de esquemas - que, embora não fixos temporalmente, não são fáceis de resistir". No entanto, defende, os constrangimentos são necessários à produção do género: os actos performativos que constituem o género não podem ser entendidos fora da repetição forçada de normas e convenções culturais (Butler 1993, pp. 94-95). Deste modo, o género não "é”, mas "faz-se" - constrói-se como uma série de actos (performativos).

A análise pós-estruturalista expandiu, pois, as investigações feministas na formação e desenvolvimento da identidade de género e sobretudo do significado de mulher universal. Mais do que compreender o género e os papéis de género como uma experiência universal, procurou-se realçar como o conceito de mulher é o subproduto de um complexo conjunto de relações sociais e culturais (Flax, 1990, pp. 52-53). Assim, à maternidade não é conferido um significado universal, mas entende-se que também ela é o produto das próprias estruturas que definem o conceito "mulher". Deste modo "o foco da interrogação feminista muda para a desconstrução 
dos valores que rodeiam o social e as funções biológicas da reprodução que constroem o conceito "mulher"' (Guerrina, 2001, p. 37).

As feministas da diferença basearam o seu entendimento das NTR na capacidade de uma mulher de estar materialmente ligada a outra vida humana, nomeadamente de um feto. Essas ligações dão às mulheres direitos e responsabilidades diferentes face a outras entidades implicadas no processo reprodutivo - não só o feto, mas também os homens e o Estado. Neste domínio, portanto, o feminismo da diferença concentrou-se nas necessidades especiais da mulher, destacando a necessidade de desafiar estruturas sociais, económicas e políticas actuais baseadas no padrão masculino de trabalho e cidadania.

As questões da identidade quando olhadas a partir das NTR não se limitam, no entanto, aos dilemas femininos. Mais em geral, mesmo considerando a reprodução um processo natural, compreende-se que o que está em causa é também um processo profundamente embutido nas instituições sociais, especialmente nas de parentesco e de família. É nesse sentido que a ideia antropológica do parentesco, que remete para o entendimento de que os factos da natureza são, na verdade, construções sociais e culturais, tem aplicações muito claras no domínio das novas tecnologias da reprodução. Como a antropóloga Sarah Franklin observa, num estudo sobre a construção social da infertilidade "está mais em jogo do que um dilema reprodutivo: não só a capacidade biológica dos casais para reproduzir, mas a necessidade da reprodução social e cultural de definições específicas de paternidade e procriação, dos valores da família tradicional e dos arranjos sexuais convencionais" (Franklin, 1990, p. 226).

$\mathrm{Na}$ construção pública do significado das novas técnicas reprodutivas, o ponto da referência é ainda a reprodução natural, mas esta é simultaneamente reinterpretada e apresentada de novos modos (Franklin, 1995; Lie, 2002). Ora, como Foucault há uns anos nos mostrou, o poder de reinterpretar e redefinir os grandes quadros de compreensão das problemáticas em torno das NTR reside, em grande parte pelo menos, no corpo de profissionais especializados que as operacionalizam. Vejamos, então, o que significa a sua intervenção nos processos de sentido.

\section{Medicalização e tecnologização do corpo e da reprodução}

A associação das NTR ao discurso médico passa por uma patologização da infertilidade que se afasta consideravelmente das perspectivas que focam as condições sócio-culturais da condição de não ter filhos. Esta patologização, nomeadamente quando associada ao discurso do "impulso maternal", no entanto, não toca apenas a condição 
de infertilidade, mas a própria mulher, contribuindo sobretudo para patologizar a mulher sem filhos. Isso mesmo é visível quando, por exemplo, a própria mulher se torna responsável pela patologia, pondo fim ao tratamento da infertilidade: ainda que, em muitos casos, essa decisão não seja "uma escolha", mas algo forçado por factores como a idade, ausência de recursos ou a recusa do parceiro, o poder do vazio criado nas mulheres inférteis fá-las distanciar-se dos seus próprios corpos, que são construídos como relativos à disfunção e não como aquilo que elas esperariam do seu próprio corpo (Throsby, 2004).

A medicalização e a tecnologização são, pois, aspectos importantes da experiência da fertilização in vitro. No entanto, recorda Throsby, não explicam tudo, e a abordagem que delas fazem muitas feministas como base de análise para as questões da reprodução não tem em conta a sua ambiguidade e ambivalência. Numa boa parte deste discurso, as tecnologias são construídas como artefactos neutrais, a ser usadas ou abusadas, ou como instrumentos patriarcais inerentemente "maus", isto é, instrumentos de opressão das mulheres. Mas, ainda que os significados das tecnologias sejam forçados por determinados discursos dominantes de reprodução e tecnologia, esses significados são "sempre provisórios e nunca absolutos" (Thorsby, 2004, p. 46). Por isso, para Thorsby, só as abordagens pós-estruturalistas, Foucaultianas, permitem uma exploração dos significados contingentes e dinâmicas e as relações de poder das tecnologias reprodutivas, um argumento que é partilhado por outras feministas neste campo.

Os escritos históricos de Foucault constituíram, como é bem sabido, um forte impulso na compreensão dos discursos como poder. Os seus clássicos como Loucura e Civilização, O Nascimento da Clínica e os três volumes da História da Sexualidade, apesar de não terem considerado o tratamento dos corpos femininos, mapearam o estabelecimento de uma "genealogia" dos discursos e constituição das práticas médicas contemporâneas que puseram em dúvida "as verdades" das interpretações históricas e mostraram como as redes do poder produzem os conhecimentos e as experiências médicas. O corpo é o lugar último de controlo político e ideológico, vigilância e regulação. Assim, para Foucault, o encontro médico é um exemplo supremo da vigilância, pelo qual o médico investiga, questiona, toca a carne exposta do paciente, testa e examina, enquanto o paciente se submete e abandona a sua jurisdição do corpo, passando-a para o médico. Em casos severos de doença ou incapacidade física, o corpo é "possuído" pelo sistema médico, enquanto na doença mental o corpo é o aparelho que guarda e contém o cérebro. O corpo humano é, enfim, o sujeito de toda a investigação e conhecimento na análise da dimensão social da medicina, podendo ser entendido nas quatro 
formas (necessariamente fluidas) que Frank (1990, p. 134) identifica: o corpo medicalizado; o corpo sexual; o corpo disciplinado; e o corpo de discurso. Como refere Teresa Levy (2004):

As biociências, as ciências médicas e as biotecnologias viajam pelo corpo medicalizado, tentando romper a densidade oculta do corpo, de modo a torná-lo descritível e explicável em termos biológicos. Ao fazê-lo definem fronteiras, instituem normas, definem modos de nomeação e estratégias para lidar com os transgressores. A medicina define a saúde como norma e policia as suas fronteiras, separando os saudáveis e os doentes, os tratáveis e os intratáveis, os puros e os infectados, isolando os grupos de riscos. Nunca será de mais frisar a importância reguladora e normativa das disciplinas e práticas à volta da doença e da saúde, da vida e da morte.

Remoaldo e Machado (2006, p. 13) fornecem-nos exemplos práticos desse poder disseminado, concluindo da sua investigação sobre a infertilidade na zona de Guimarães que "um dos principais resultados do nosso estudo é a preferência dada à paternidade biológica e o sentido de que ter um filho biológico era o maior sonho da mulher". Também Amélia Augusto (2006) se refere ao facto de os especialistas, nos seus discursos, reforçarem implicitamente a ideia do pressuposto da heteronormatividade que é assumido com o estado natural das relações. Tal está claramente assumido pelos condicionalismos da actual Lei sobre Procriação Medicamente Assistida.

O discurso da ciência liga-se a outros discursos poderosos, como o judicial, no controlo e regulamentação do comportamento sexual e procriativo da mulher. Diz ainda Helena Machado a propósito do uso judicial de exames genéticos para investigação de paternidade:

O crescente interesse do sistema jurídico português pela "bio-identidade", ou identificação genética de um indivíduo, alicerça-se na crença de que esta prova biológica veio introduzir uma maior "certeza" da paternidade no direito da filiação. A crença na quase "certeza" absoluta da determinação da paternidade é substanciada pela imagem de neutralidade e rigor que veicula o discurso da comunidade científica que realiza os testes genéticos a pedido dos tribunais (Machado, 1999, p. 18).

No mesmo sentido, antropólogos e sociólogos da saúde e da doença começaram a pôr em dúvida as pretensões de "verdade" e neutralidade política do conhecimento biomédico. O que se afirma como "verdade" deveria ser considerado o produto de relações de poder e, como tal, nunca neutral, mas sempre ligado aos interesses de alguém. Todos os 
conhecimentos são inevitavelmente os produtos das relações sociais, modificando-se. O conhecimento não é uma realidade universal, independente, mas participa na construção da realidade. Neste sentido, também os sujeitos humanos podem ser examinados como constituídos em e por discursos e práticas sociais que têm histórias complexas. Na sua relação com a biomedicina, entende-se que os estados e as experiências de saúde e doença são conhecidas e interpretadas através da actividade social e por isso devem ser examinadas pela análise cultural e social. Do mesmo modo, o conhecimento médico não deve ser considerado como uma progressão em direcção a um conhecimento mais refinado e melhor, mas como uma série de construções relativas que dependem dos ambientes socio-históricos que os rodeiam e que obrigam à sua constante renegociação.

O modo como os corpos são tratados na medicina e a forma como podem ser experienciados e formados via sexo ou género aliaram-se num crescente questionamento do corpo. Nos últimos anos, com efeito, a compreensão do corpo natural foi exaustivamente questionada e escrutinada por cientistas sociais, historiadores e filósofos que radicalmente colocaram em causa a ordem sexo versus género de uma nova forma: "poder-se-ia dizer que as investigadoras feministas antes procuraram alargar o alcance dos factores sociais e culturais, isto é, o género, diminuindo assim os efeitos da biologia. O contributo dos estudos de ciência, no entanto, consistiu em destabilizar o sexo como natureza" (Lie, 2002, p. 386).

A ciência fornece-nos importantes modelos culturais (Lupton, 1994; Lie, 2002). Conta-nos histórias sobre o nosso mundo biológico e social, em modos que podem, por exemplo, explicar a diferença sexual num enquadramento largamente heteronormativo. Desse modo, Emily Martin (1991) mostrou-nos o romance do óvulo e do esperma e forneceu-nos uma explicação de como os papéis de género são atribuídos às células. Do mesmo modo, Laqueur conta como, depois da descoberta das células de óvulo e esperma, as relações sexuais foram representadas como um casamento: "a fertilização tornou-se uma versão miniaturizada do matrimónio monogâmico, onde o animálculo/marido conseguiu passar pela abertura única do óvulo/esposa, que então se fechou" (Laqueur, 1990, p. 172). Mas uma das críticas mais profundas que se pode fazer às explicações científicas (biológicas) modernas da concepção é, como recorda Franklin (2006), compreender que elas têm dois objectivos primários: explicam a casualidade da concepção como um mecanismo biológico em particular e, pela sua própria acção, demonstram (simbolica e literalmente) o poder dessas explicações em geral. A versão científica da concepção assistida confirma ainda mais este processo: é porque temos uma explicação exacta, efectiva, científica, e objectiva dos mecanismos da concepção que a ciência moderna pode intervir com sucesso para 
consertá-los. Apesar desta auto-referencialidade, a ciência, na verdade, não se limita a "dar uma ajuda" à natureza, mas substitui todo o ciclo da concepção por um outro. Mas estes aspectos paradoxais são diluídos quando a ciência se apresenta como "uma tecnologia de esperança" (Franklin, 1997) articulada com investimentos personificados em valores culturais específicos, como progresso científico.

São múltiplos os efeitos de se considerar a relação dos corpos com a ciência e a tecnologia. A ela vem associada, por exemplo o problema do desaparecimento do corpo (disembodiment). Com efeito, como refere Carla Lam (2004), uma das formas mais óbvias de profunda transformação do papel outrora central da mulher na reprodução é o modo como ela se torna literalmente invisível pelas NTR, podendo mesmo argumentar-se que as tecnologias de visualização fetais eliminam literalmente as mulheres e transformam os embriões/fetos em seres independentes. Aqui, as consequências da intersecção entre tecnoconhecimento e desaparecimento de mulher são claras, mostrando também a intersecção entre a descorporização física e conceptual.

O discurso da ciência é, naturalmente, o primeiro a produzir os corpos com género. Definindo óvulo e esperma como versões metonímicas de mulheres e homens, Spilker e Lie defendem que o debate norueguês contemporâneo sobre a doação de ovócitos contém uma "guerra sexual implícita" combinado com uma ênfase explícita nas oportunidades iguais. "O aspecto da guerra sexual" refere-se à questão da paternidade: uma mãe é mais importante para uma criança do que um pai, ou são simplesmente iguais? Se existe há tanto tempo acesso à doação de esperma, porque não permitimos a doação de ovócitos? Há alguma diferença básica - e isto é uma questão de igualdade ou diferença sobre as células, ou sobre mulheres e homens? (Spilker e Lie, 2007, p. 329-330).

Para Laqueur (1990), o reconhecimento das diferenças biológicas como decisivas para as diferenças de género sociais é uma construção cultural que apareceu numa determinada época da história ocidental, dado que, noutros tempos, outras teorias da diferença eram proeminentes. Mas a questão da semelhança e da diferença sexual como núcleo da identidade dividiu profundamente as feministas. Por isso Donna Haraway (1990) vai mais longe na sua análise, não se limitando a reconhecer os aspectos culturais desta construção ou a referência à biologia frequentemente acusada de "essencialista". Na sua crítica aos discursos que procuram definir uma identidade feminina, ela propõe a ideia de ciborgue - um organismo cibernético que impede essa definição. Dada a sua posição híbrida, a capacidade de esta figura ilustrar o apagamento das fronteiras entre humanos e máquinas, humanos e imagens, resistindo à própria definição do orgânico ou do corpo "natural" personifica também um 
desafio das categorias convencionais de raça, género, natureza e humanidade, colocando em dúvida a impermeabilidade de todas estas categorias. O ciborgue exprime um ideal de "um híbrido humanóide", combinação de humanidade e tecnologia em que as categorias de sexualidade, étnica, género e a própria distinção entre humanidade e tecnologia são indeterminadas e fluidas. Os ciborgues transcendem assim os processos dualistas sobre os quais a modernidade ocidental, o patriarcado e o colonialismo foram fundados, falando não da hierarquia da humanidade, tecnologia e natureza, mas da interdependência e permeabilidade de todas essas categorias. Esta é, pois, a figura pela qual Haraway que procura envolver-se na agenda de uma biopolítica crítica, resistindo simultaneamente a tendências puritanas e considerando todos os aspectos a que havia que resistir - como o conceito de tecnosciência.

Apesar da radicalidade destas críticas pós-modernas às narrativas fundacionais que tendem a produzir um relativismo e ausência de bases operacionais, é possível, como defendem Fraser e Nicholson, reconciliálas com a força da crítica social do feminismo, gerando "a contraparte teórica de uma solidariedade feminista mais vasta, mais rica, mais complexa e multifacetada, o tipo de solidariedade que é essencial para superar a opressão de mulheres na sua "variedade infinita e semelhança monótona" (Fraser e Nicholson, 1990, p. 35). Uma forma de gerar essa solidariedade é, precisamente, compreender como os feminismos, que percorrem o espectro que vai do essencialismo biológico às perspectivas construcionistas sociais, se podem articular publicamente.

Em todas as expressões do feminismo moderno ou pós-moderno, ou do debate igualdade/diferença, com efeito, estão em causa perspectivas relativas ao alargamento e protecção dos direitos das mulheres. A posição das "feministas de igualdade" procura minimizar o impacto das diferenças sexuais no processo legislativo, defendendo que a sociedade deve tratar as pessoas segundo as suas características, independentemente do género, mais do que acentuar as diferenças individuais e reforçar os pressupostos sociais baseados em estereótipos. Justificam esta posição defendendo que pôr de parte as questões sobre a natureza e os papéis da mulher permite ao movimento feminista, no plano político, focar a realização dos direitos iguais, salários e mesmo oportunidades iguais, melhorando a posição das mulheres na esfera pública (Phillips, 1987, pp. 5-7). Pretende-se, assim, expandir a igualdade formal, alargando as ideias liberais tradicionais que promovem a autonomia individual e o privado. $\mathrm{O}$ facto de as autoridades legais reconhecerem hoje a importância da autonomia pessoal e do privado na arena dos direitos reprodutivos, defendendo o direito de uma mulher de terminar a sua gravidez e de procurar novas tecnologias de reprodução é, em grande parte, resultado deste trabalho. No outro lado 
do debate, "as feministas da diferença" favorecem o desenvolvimento de políticas baseadas nas necessidades das mulheres como mulheres. O seu pressuposto é que "para as mulheres terem um direito igual a trabalhar, por exemplo, podem precisar, de facto, de mais do que os homens" (Phillips, 1987, p. 8).

Como se pode, então, equacionar este debate com as questões do espaço público? Para pelo menos esboçar um princípio de resposta, precisamos de convocar mais alguns actores-chave: a ciência e o modo como ela se articula publicamente num espaço essencialmente mediatizado.

\section{Ciência, espaço público e espaço mediático}

Os meios de comunicação constituem a principal arena onde as controvérsias e as questões científicas chegam ao público, aos grupos de interesse e aos decisores políticos. Não só influenciam a atenção dos actores políticos e do público, como moldam o modo como as questões da tecnologia e da ciência são definidas, simbolizadas e, enfim, resolvidas. Numa democracia mediada, com efeito, os eventos que se realizam na esfera política e os grupos que competem no sistema político não são simplesmente reflectidos nos meios de comunicação, mas são também formados por eles. Nesse sentido, os media são uma instituição política, que tem contacto directo com o domínio político, seleccionando fontes e histórias possíveis e definindo as problemáticas com determinadas ênfases e ângulos de abordagem.

Neste espaço mediatizado, as questões são produzidas por processos de definição colectiva, mas o que poderíamos reconhecer como propriedades objectivas intrínsecas não explicam como o problema é constituído. A definição dos problemas é, antes, uma construção social contínua, uma luta interpretativa que não tem lugar em qualquer domínio vago como "a sociedade" ou "a opinião pública", mas em determinadas arenas públicas concretas, onde os problemas sociais são articulados e enquadrados (Maeseele, 2007). Estas arenas não são uma só: são múltiplas e recobrem instituições como as universidades, os centros de investigação, os governos, os parlamentos, as instituições político-jurídicas, as ONG e, certamente, os meios de comunicação que incluem notícias, espaços informativos da mais diversa índole da Internet, blogues, etc.. Dado não só o seu alcance social, como a sua centralidade na pressão pública sobre os líderes políticos para agir de determinadas formas, é à arena pública dos media que os estudos de comunicação de massa prestam uma atenção particular. E os media são, de facto, um lugar importante para estudar as definições colectivas e a construção social contínua, cuja análise deve 
necessariamente ser mais complexa do que o habitual olhar que sobre eles se lança. Longe de serem uma simples correia de transmissão de uma comunicação que parte de um qualquer centro "autorizado" de emanação das definições "certas" para um público que as recebe de modo acrítico e passivo, precisamos de entender o seu papel na criação do significado relacionado com saúde, doença e medicina.

Uma grande parte da investigação em torno desta questão tem sido fundada no pressuposto de que os media têm pelo menos alguma influência cognitiva, afectiva, e/ou comportamental sobre os destinatários das suas mensagens. Nesse sentido, procura-se avaliar as mensagens a que as pessoas são expostas, centrando-se no que é dito nesses retratos (Hodgetts \& Chamberlain, 2006, Augusto, 2004). Ainda que haja numerosos métodos específicos para a análise dos textos mediáticos, a maior parte destes estudos tende, no entanto, a adoptar a análise de conteúdo e, em menor grau, a abordagem analítica ou interpretativa/ crítica. Menos trabalho se tem concentrado em investigar como se produz a cobertura de saúde a partir das salas de redacção e da relevância das culturas jornalísticas. Menos estudos ainda exploraram as respostas do público ao conteúdo de saúde nos media (Kline, 2006).

Nesta literatura, a ideia mais recorrente é que os media, por um lado, enfatizam excepcionalmente o progresso médico, muitas vezes ignorando ou exagerando os insucessos da medicina e, por outro, relatam os problemas, medos e inquietudes associados aos avanços da ciência em termos irrealistas e sensacionalistas. No entanto, essa análise é com frequência falaciosa. Por um lado, é difícil sincronizar a informação fornecida por fontes científicas com a que surge nas notícias e determinar qual o grau de compatibilização de informação complexa e contingente que é passada aos jornalistas, que têm habitualmente como registo discursivo o texto directo, sucinto e por vezes dramático, um registo que quase sempre conta uma "história". Por outro lado, uma boa parte do campo de investigação e prática que normalmente aparece como "comunicação de saúde" é ainda dominada por modelos psicológicos comportamentalistas e perspectivas teóricas que devem muito ao modelo de comunicação estímulo-resposta e a ideais de comunicação estratégica que colocam o poder de criar "boas mensagens" num "saber comunicar" que basicamente procura construir o sentido de um modo estratégico e interessado.

Dorothy Nelkin (1987) caracteriza a década de 1970 como uma época em que o jornalismo abordava o campo científico com "espanto e desconfiança". Foi sobretudo com espanto que o advento das tecnologias reprodutivas, protagonizado pelo nascimento de Louise Brown, o primeiro "bebé-proveta", foi visto na imprensa britânica e nos seus ecos internacionais, incluindo os jornais portugueses. Este "acontecimento 
mediático" produziu uma verdadeira "histeria" nos media. Não sendo totalmente acríticos, os jornais narraram uma história onde, "a maior parte (...), tanto no Reino Unido como na América, assumiu a posição implícita de que o homem activo havia agido, uma vez mais, fazendo um enorme favor às mulheres passivas" (O'Brien, 1979, p. 61). O mesmo espanto e também preocupação encontraremos em outras notícias posteriores, como mostra Cristina Ponte (2002) na sua análise das notícias internacionais do nascimento de Adam Nash. As formas narrativas, o uso das citações e a contextualização nacional são estratégias jornalísticas que a sua análise explora, delimitando "um território a estudar, onde a simples dramatização e a canalização para o 'interesse humano' pode constituir uma limitação à necessária contextualização e problematização política, cultural e social das questões na esfera pública" (Ponte, 2002, p. 82).

Pelo seu lado, os cientistas foram tomando consciência da importância da sua imagem pública e progressivamente foram alterando o modo como se relacionam com a imprensa. Hoje, refere Van Dyck (1995, p. 46), "a informação tornou-se um bem valioso para os cientistas, ou mais precisamente, para os investidores no campo da saúde". Daí, o crescente profissionalismo com que a ciência se "apresenta" aos e nos media.

$\mathrm{O}$ facto de a ciência fornecer aos jornalistas um imenso manancial de histórias e de o jornalismo ser necessário aos cientistas aproxima os dois campos. Nesta aproximação, algumas das ferramentas profissionais parecem fundir-se, nomeadamente no modo como as invenções científicas aparecem como "factos da vida", normalmente indisputáveis. A apresentação dos "factos" e do ideal da objectividade é no jornalismo, como na ciência, um meio de auto-legitimação que presume a ausência de um sujeito narrador. Todo o aparato de infografias, imagens e estatísticas que vemos hoje nos media, quando falamos de saúde, é um domínio jornalístico especializado que trabalha de muito perto com os cientistas. O resultado é uma crescente legitimação dos respectivos poderes: o de fazer ciência "pública" e o de fazer informação "pública".

Uma análise destes campos implica ir além da análise da superfície dos textos e o primeiro passo para isso será reconhecer que a cobertura de saúde não é apenas um canal da transmissão da informação sobre esta, mas um fórum da construção social de compreensões públicas do risco, da doença e da saúde e que é central à reprodução de relações sociais e estruturas que as envolvem (Lupton, 1994b; Wallack, 2003). Neste aspecto, a investigação indica que a cobertura noticiosa tende a acentuar uma abordagem médica à saúde, concentrando-se nos esforços dos médicos e dos investigadores biomédicos, nas necessidades de estilo de vida individuais e nas respectivas possibilidades "curativas" (Seale, 2003). Isto resulta na despolitização da saúde, transformando-a num objecto e 
numa responsabilidade individual e não tanto numa questão de acção colectiva (Hodgetts, Bolam \& Stephens, 2005, Hodgetts \& Chamberlain, 2003, 2006). Diz Wallack (2003, p. 338):

A importância dos media depende da forma como conceptualizamos a natureza das questões de saúde pública e portanto das suas soluções (...). Se os problemas de saúde pública forem examinados como basicamente enraizados nos comportamentos pessoais que resultam de uma falta do conhecimento, então os media são importantes porque podem ser um mecanismo para dar a informação certa às pessoas (...) para promover a modificação pessoal. Se, por outro lado, os problemas de saúde pública forem examinados como basicamente enraizados na desigualdade social que resulta da forma como usamos a política de organização da nossa sociedade, então os media são importantes porque podem ser um veículo para aumentar a participação na vida cívica e política e no capital social para promover a mudança social.

Assim, um dos trabalhos mais citados sobre as representações populares da infertilidade é o da antropóloga Sarah Franklin, que as identificou deste modo:

A descrição típica do infértil enfatiza o seu "desespero", a sua "angústia" e "sofrimento" e refere-se a elas como as "vítimas de não poder ter filhos", os que "não têm filhos contra a sua vontade", os que "não têm filhos involuntariamente", os "que sofrem de infertilidade". Justapostas a estes contos do "desespero" aparecem as histórias dos casais felizes que ganharam a batalha contra a ausência de filhos produzindo um "bebé-milagre" com a ajuda da moderna ciência médica (Franklin, 1990, p. 200).

Esta "linguagem do desespero", com frequência usada para caracterizar a busca de concepção por mulheres e casais inférteis, articula-se com três grandes tipos de discurso que organizam as representações médicas e mediáticas da infertilidade: o discurso da perda social, do destino biológico e da esperança médica (Franklin, 1990, 1997). Maioritariamente, as narrativas sobre casais ou sobre mulheres sem filhos desenvolvem-se mediante a história do desespero por uma criança e o aparecimento das novas tecnologias reprodutivas como a sua "solução óbvia". Deste modo, estas mesmas histórias normalizam as tecnologias, ignorando as taxas de insucesso, os custos envolvidos, os processos traumáticos por que a mulher tem de passar e as questões éticas e morais levantadas. Nas suas palavras: 
É a perturbação da progressão normal nas vidas da 'maior parte dos indivíduos' que lhes faz 'sentir que perderam o controle' e sofrer das 'ansiedades' sobre a sua infertilidade. Social e emotivamente, o stress da ausência de filhos é atribuído ao fracasso na realização dos papéis adultos convencionais e ao fracasso de 'fundar uma família'. A causa 'do desespero', noutras palavras, é representada como um fracasso de conformar-se às normas sociais (Franklin, 1997, p. 91)

E Franklin mais adiante continua:

Neste domínio altamente naturalizado, então, introduz-se a ciência médica, em nome dos casais estéreis 'desesperados' para quem 'a progressão de vida' foi mantida refém da injustiça da lotaria da natureza de os tornar incapazes de conceber. É esta a ligação crítica nas representações de meios de comunicação populares (Ö) onde o desejo 'desesperado' de uma criança fornece o caminho para 'a esperança médica de uma cura' (Franklin, 1997, p. 92).

Além disso, os media e as explicações médicas invariavelmente associam a ausência de filhos a casais casados, heterossexuais, deixando de fora as razões estruturais como o desemprego, os baixos rendimentos, os cuidados infantis, a preferência sexual ou o estado civil. A "cura" para a infertilidade, assim, surge nos media mais frequentemente retratada como tratamento médico e não tanto associada à mudança social (Franklin, 1990, p. 220-221).

Os discursos dominantes da fertilização in vitro tendem, por outro lado, a ficar entre dois pólos: a fertilização in vitro como a ciência benigna dando a mulheres desesperadas (e não aos casais) uma ajuda, e a fertilização in vitro como um pesadelo que ameaça a ordem "natural" da reprodução para cumprir visões Frankensteinianas (Thorsby, 2004, pp. 2-4). Comummente, o factor de união dos cenários desiguais na percepção pública é a ideia de que a fertilização in vitro é geralmente "um êxito" que resulta num nascimento vivo. O que os retratos públicos não reflectem é a sua "experiência mais mundana, diária" (Thorsby, 2004, p. 6) e a experiência do insucesso que é significativa com todas as diversas técnicas reprodutivas, sejam elas a inseminação artificial, a fertilização in vitro, a transferência intra-tubária de zigotos ou gâmetas ou a injecção intracitoplasmática.

Jana Sawiki (1991, p. 73) faz notar que muito do discurso das feministas radicais é demasiado pessimista e unidimensional, demonizando as tecnologias e os homens que as criaram. Por outro lado, ignora os múltiplos papéis das mulheres e a diversidade de formas como os 
úteros das mulheres podem ser disciplinados e controlados: enquanto mães, trabalhadoras, donas de casa, parceiras sexuais, etc.. Por isso, são necessárias mais análises que clarifiquem por que as mulheres acham essas tecnologias benéficas e é necessário encontrar os lugares de resistência. As mulheres não são vítimas colectivas das tecnologias e da instituição médica, nem tão-pouco são simplesmente suas beneficiárias. Anne Balsamo sugere que

As feministas pensam sobre as tecnologias como formações em e de si próprias - não como processos isolados ou artefactos materiais (...). Uma das consequências desta mudança é compreender que haverá menos pressão para produzir e defender uma avaliação-base de uma dada tecnologia. Isso encorajará as feministas a pensar de um modo mais complexo sobre as inter-relações entre os dispositivos tecnológicos, o conhecimento especializado, as práticas científicas, e um contexto cultural mais vasto que é historicamente determinado de várias formas e materialmente enraizado (Balsamo, 1996, p. 96).

É precisamente esse contexto e as estruturas que lhe estão subjacentes que formam o quadro de interacção entre os vários intervenientes que vemos (e não vemos) presentes no espaço público mediático.

\section{Espaço público e tecnologias reprodutivas}

Uma perspectiva que concebe a sociedade em termos habermasianos e que nos pode ser útil para pensarmos o espaço público é a de Graham Scambler (1987). Numa arquitectura habermasiana da sociedade, o bem-estar social depende de um equilíbrio crítico entre, por um lado, os processos sociais que reproduzem as tradições culturais, integração social e a identidade pessoal (o mundo da vida) e, por outro lado, as actividades relacionadas com operações económicas/produtivas necessárias para a sobrevivência física (os sistemas). Os sistemas são o lugar da reprodução material (economia e administração do Estado) por oposição à reprodução simbólica da vida social, função que compete ao mundo da vida, lugar da transmissão do conhecimento cultural e da resolução de discordâncias sobre matérias éticas e normativas. Scambler segue a tese habermasiana do desequilíbrio causado pela preponderância da racionalidade própria dos sistemas sobre o mundo da vida. Equaciona, assim, as manifestações profissionais e institucionais da medicina científica moderna com o "sistema", argumentando que a racionalização do sistema na esfera da saúde e doença, de facto, levou a uma colonização médica do mundo da vida. Tomando como exemplo principal a "medicalização" do parto, para 
Scambler esta colonização é visível "na mudança da casa para o hospital como o lugar típico para o parto (isto é, o crescimento do poder territorial), e na crescente ênfase da gestão activa do trabalho e do parto (isto é, o crescimento do poder tecnológico)" (Scambler, 1987, p. 175). No entanto, poderíamos pensar nos mesmos termos relativamente a outras condições como a menopausa ou a infertilidade: ao serem apropriadas pelo domínio especializado, técnico e tecnocrático, mais dificilmente se tornam questões de discussão na esfera pública, onde as questões de natureza moral e prática poderiam ser equacionadas. A medicina, nestes termos, torna-se um sistema perito enormemente poderoso situado numa esfera onde a apropriação das definições médicas não pode ser facilmente desafiada. Apesar disso, é importante realçar, como o faz Graça Carapinheiro, que

Quando os saberes profissionais entram em relação nos diferentes contextos de saúde, fazem-no não só a partir de referências culturais diversas, presas aos particularismos lógico-formais dos seus saberes e às especificidades sócio-culturais dos seus modelos normativos de acção, como também o fazem a partir de posições estruturais diversas na divisão do trabalho, onde se inscrevem autoridades diferenciadas, poderes desiguais e relações de trabalho em conflitualidade social (Carapinheiro, 2006, p. 148).

Por outro lado, precisamos de alargar a nossa compreensão dos modos de circulação e de experiência do saber que são constitutivos de nós mesmas/os. Giddens (1990) argumentou que, numa sociedade caracterizada pela reflexividade, a perícia técnica é constantemente reapropriada pelos agentes leigos, como parte da sua forma de lidar regularmente com ela. Ninguém se pode tornar perito, no sentido da posse de pleno conhecimento, em mais do que alguns pequenos sectores do complexo sistema de conhecimento. No entanto, a interacção com sistemas abstractos implica que ela seja situada também no mundo da vida, pela apropriação de alguns dos princípios rudimentares em que os sistemas se baseiam (Stevenson e Scambler, 2005).

Se entendermos as questões da saúde sexual e reprodutiva como um domínio de justiça, onde os actores afectados por elas têm uma palavra a dizer, teremos que reconhecer que a mobilização em torno da desejada mudança política e estrutural, por avanços substantivos na esfera pública, só pode ser conseguida pelas políticas dos novos movimentos sociais que se podem aliar ao activismo, nas fronteiras entre o sistema e o mundo da vida (Scambler, 1996, p. 578 ).

A circulação de discursos no interior do espaço público pressuporia, no entanto, um dialogismo de que a comunicação pública de saúde está 
longe, especialmente no que toca à ênfase das campanhas de educação de saúde. Exercida "de cima para baixo" são facilmente identificados nesta comunicação traços paternalistas, onde os que têm o conhecimento médico ou conhecimento de saúde pública - médicos ou outros profissionais dos cuidados de saúde - percebem o seu papel como disseminador da mensagem "certa" às massas, para seu bem. Neste processo, os membros do grande público são muitas vezes considerados apáticos e ignorantes e a quem é difícil comunicar (Lupton, 1994a, p. 56).

A esta ausência de fluxo comunicativo regular e paritário liga-se outro factor que faz do espaço público sobre as Novas Tecnologias Reprodutivas um espaço desigual: a centralidade que nele têm os media. O problema com esta centralidade é que, segundo uma boa parte da investigação crítica, os media marginalizam certos interesses e privilegiam outros, ainda que também se possa argumentar que há mais multivocalidade no discurso político do que estas análises supõem (Kline, 2006). Ora, isto é importante porque importa conhecer os contornos de uma aparente hegemonia que contribui para a manutenção de certos interesses ou para a afirmação de discursos binários ou de oposição, constituindo, desse modo, diferenciais de poder social, no privilegiar dos grupos poderosos e na marginalização dos grupos subordinados.

Essa análise, no entanto, deve contemplar uma compreensão dos media que, por um lado, dê conta da sua lógica interna, dependente não só de estruturas económicas como, e sobretudo, de procedimentos profissionais e que, por outro lado, dê igualmente conta da sua dependência da linguagem do mundo da vida, de onde os media são enxertados.

$\mathrm{Na}$ verdade, não basta estudar as representações mediáticas como algo que reflecte de modo positivo ou negativo as questões da saúde, mas também não podemos ignorar que estas mensagens influenciam - muitas vezes de modo não intencional - os conhecimentos e ideologias públicos sobre doença e saúde (Kline, 2006). Mais do que procurar visões "estereotipadas", "certas" ou "erradas" nos media é importante situar os discursos neles e por eles produzidos num nexo de vozes com maior ou menor poder para intervir no espaço público, engendrando desse modo, em articulação com o discurso jornalístico, focos plurais e alternativos à mera construção hegemónica de uma certa importância da necessidade da ciência. Isto é especialmente crucial quando, como no caso das Novas Tecnologias da Reprodução, estão em causa elevados interesses económicos privados e onde o argumento do "mercado livre" e da "escolha" (leia-se, o estilo de vida), é com frequência usado para reforçar as injustiças sociais e as práticas discriminatórias.

Por outro lado, é preciso ainda localizar nesse espaço mulheres e homens que não são apenas consumidores dos produtos de saúde ou 
consumidores de informação, mas que constroem sentidos de modos próprios e constitutivos das suas identidades. Assim, quando uma mulher exige a legitimidade de viver uma vida como mãe sozinha, sem qualquer relacionamento afectivo ou sequer contacto físico com um possível pai biológico da sua criança, por exemplo, na verdade está a fazer duas exigências: por um lado, que lhe seja reconhecido o direito a desenvolver uma identidade e um modo de vida cultural diferente do da norma familiar e parental; por outro, que lhe seja concedido o poder material de fazer essa opção.

O domínio de justiça onde esta exigência de direito reprodutivo se insere toca, pois, dimensões culturais e materiais. A dimensão pública normativa da saúde sexual e reprodutiva em geral e das Novas Tecnologias Reprodutivas (NTR) em particular pode, assim, ser entendida à luz da teoria da justiça de Nancy Fraser, que aborda as práticas normativas que competem pela legitimidade no espaço público em termos do que ela chama "reconhecimento" e "distribuição", isto é, tratando "cada prática simultaneamente como económica e cultural" (Fraser, 2003, p. 63). Com efeito, uma análise do que são as questões das NTR, quando colocadas no espaço público, não se pode limitar a uma perspectiva de justiça unidimensional, que trate apenas da identidade cultural ou apenas dos recursos materiais que lhe estão associados e da sua distribuição. Na teoria da justiça de Fraser, o reconhecimento refere-se às lutas que derivam da tensão entre normas igualitárias e hierarquias de status e a transposição para o espaço público das NTR traduz precisamente essa tensão. Assim, além da dimensão cultural das identidades nas questões da saúde sexual e reprodutiva que analisaremos de seguida, defendemos que elas dizem simultaneamente respeito a um bem que deve ser distribuído de forma equitativa. Isto é, não dizem respeito apenas a uma questão de "escolha" de um determinado estilo de vida, ou não são apenas uma questão de vida boa, mas são relativas a direitos que, não sendo respeitados, traduzem uma forma de opressão e uma subordinação sistémica que é também económica e de poder. Para as compreender, procuraremos explorar alguns dos seus contornos paradoxais, centrando-nos nas suas dicotomias para, enfim, diz Fraser (2003), as derrotar.

A forma como nos organizamos subjectiva e colectivamente constitui o modo de acesso tanto ao poder discursivo como ao poder político, isto é, à justiça entendida como distribuição de recursos culturais e materiais.

Para as mulheres, a fragmentação da maternidade tem sido acompanhada de uma desintegração de vozes segundo eixos identitários, como atrás demos conta. Talvez isso seja inevitável dada a sua pluralidade e diversidade; mas, precisamente por isso, importa pensar no espaço público como uma arena útil, constituída por diversos "círculos", para examinar 
as implicações de uma justiça que articula questões de subjectividade e autodeterminação com matérias de regulação colectiva. Esta regulação, nas esferas "formais" de decisão (governos, parlamentos, aparelho jurídico), necessita dos inputs desses círculos para se constituir como a base legítima da autodeterminação, encontrando uma forma constitucional e uma garantia de institucionalização. Um espaço público paritário, por outro lado, conjuga autonomia e autoridade. Como referem Myra Ferree e William Gamson: "a autonomia tem que ver com a governação do género, ou com as formas como a sociedade e o Estado controlam a autodeterminação das mulheres e homens como indivíduos, e a autoridade tem que ver com o 'gendering' da governação, ou o acesso que os homens e as mulheres têm à tomada de decisões que regulam a vida comum dos grupos sociais" (Ferree e Gamson, 2003, p. 37).

O espaço público, nestes termos, implica a inclusão pela participação e influência sobre o significado da cidadania. Construindo-se a partir da identificação de uma gramática moral da exclusão, da desvantagem e da marginalização da vida social e indo simultaneamente além das fórmulas do universalismo individual, este espaço público articula autonomia com poder, coloca de um modo explícito as questões da identidade no seu centro e faz do reconhecimento a principal estrutura da criação de exigências sobre cidadania e justiça.

Como estrutura de cidadania, o espaço público é o resultado de constrangimentos e oportunidades para avançar exigências de reconhecimento, alterar práticas de exclusão e realçar direitos participativos que afectam a redistribuição de recursos. Numa democracia "realmente existente", como Nancy Fraser (1992) já lhe chamou, estas dimensões são equacionadas em torno de questões concretas que trazem à luz formas de compreensão da subjectividade individual e colectiva e do poder discursivo que moldam as próprias exigências articuladas publicamente. Assim é com o domínio das tecnologias reprodutivas, como vimos. Mas se as elas dividem as mulheres no que toca ao reconhecimento de uma subjectividade associada ao que essas tecnologias envolvem, o que é essencial é que sejam criadas condições formais para uma verdadeira paridade no avanço das exigências.

O discurso dos media é, certamente, uma poderosa forma de moldar essas exigências, e não pode ser ignorado que ele convoca actores com lógicas próprias de mediação que não coincidem necessariamente com as dos restantes actores envolvidos. Apesar disso, não podemos esquecer que a ligação entre os conceitos de "espaço público" e "espaço público mediático" é muito forte e complexa, não podendo ser reduzida a dois domínios interligados simplesmente por correias de transmissão. 


\section{Conclusão}

Ao longo deste texto, fomos desenvolvendo a premissa que as questões reprodutivas (concepção, contracepção, maternidade, fertilidade, etc.) não são simplesmente explicáveis pela natureza biológica, mas que adquirem significados através das crenças culturais e se formam pela acção das instituições sociais, médicas e políticas. Nesta construção cultural intervêm vários autores que se cruzam no espaço público com as suas lógicas próprias, construindo publicamente os seus significados.

O lugar privilegiado da visibilidade dessa construção são os media que ocupam uma posição central no espaço público e que, por isso, são um alvo preferencial nos estudos sobre o entendimento da saúde. No entanto, a compreensão da comunicação da saúde não pode limitar-se à análise da superfície dos textos mediáticos, como se eles fossem apenas o resultado individual de escolhas jornalísticas idiossincráticas; não pode sequer limitar-se a julgá-las como mais próximas ou mais distantes de uma suposta "verdade científica", ignorando as dimensões políticas e sociais que, em articulação com outras, produzem esse discurso. Como vimos, há cada vez maiores ligações entre o discurso jornalístico e o discurso da ciência que colaboram no sentido de apresentarem ao público uma informação "distanciada", "factual" e objectiva. Os contornos dessa proximidade e também diferença deverão ser explorados a partir de um conhecimento das lógicas de cada um dos campos sociais. Por outro lado, é igualmente fundamental interrogar criticamente o significado e implicações da compreensão pública da saúde no quadro de um espaço público normativo, entendido a partir das transformações culturais que caracterizam as sociedades contemporâneas. Os desenvolvimentos na teoria feminista, sociológica, filosófica, histórica, e antropológica sobre o corpo como um lugar de controlo e de articulação da subjectividade, o discurso médico como poder e a medicina como uma instituição do controlo social têm muito a oferecer à compreensão da dimensão sociopolítica do encontro médico e das crenças leigas sobre a saúde.

A perspectiva crítica face às Novas tecnologias Reprodutivas assume uma abordagem publicamente política, interrogando os valores da biomedicina e concentrando-se na identificação dos factores políticos, económicos e históricos que formam as respostas culturais aos conceitos de saúde, doença e tratamento, reconhecendo-os também como produtos dos sistemas sociais e processos ideológicos. A teoria cultural crítica mostrou que as formas comuns de conceptualizar a doença ou a ameaça da doença na sociedade Ocidental incorporam muitas vezes imagens e metáforas a partir de uma série identificável de discursos que incluem noções de higiene e asseio, a guerra, a invasão, o medo, a morte, a 
violência, o apocalipse, a masculinidade/feminilidade, a tecnologia/ maquinismo, o desastre e o milagre (Lupton, 1994b). Assim, como diz Deborah Lupton:

Até a comunicação de saúde como um campo novo e multidisciplinar reconhecer os recentes desenvolvimentos na teoria social e política, dos media e estudos culturais, da análise de discurso, e da sua aplicação à comunicação nos cuidados de saúde, fica destinada a permanecer uma versão derivada, paternalista, e estreita da educação para a saúde (Lupton, 2004a, p. 64).

É este quadro de compreensão que deve moldar as nossas abordagens ao discurso social sobre as experiências de infertilidade que são, como todas as outras experiências, afectadas pelos discursos que as envolvem: médico, profissional, político, económico e jornalístico, que constroem uma certa visão dela (Letherby, 2003 , p. 50).

Muitos dos discursos médicos e profissionais que constituem a via privilegiada de acesso aos media centram-se em definições oficiais aparentemente neutras e estritamente "científicas", mas que estão sempre embuídas de implicações morais (Turner 1996, p. 97). Por outro lado, a saúde pública contemporânea é hoje também um empreendimento político e económico que se situa dentro de um discurso que, por um lado, sublinha as responsabilidades e os deveres que os indivíduos devem assumir em relação aos seus corpos, em troca do privilégio da cidadania (Petersen \& Lupton, 1996) e que, por outro, faz emergir um "empresário de si mesmo". Este é o sujeito de quem se espera que viva a vida de um modo prudente e planeado, bem informado e atento aos riscos ao corpo - uma visão profundamente ligada a uma política de distribuição que é produto do fim do Estado de bem-estar e da crescente confiança nos mercados para regular os espaços do privado e do público.

É precisamente aqui que, como vimos, entra o segundo elemento da teoria bi-focal de Nancy Fraser. O foco sobre de quem são os direitos a proteger e que tipo de organização social é preferido constitui o poder de inclusão e de exclusão que molda a distribuição de recursos (económicos e culturais), determinando, desse modo, a configuração das nossas sociedades.

A transparência com que o discurso liberalizador da saúde e do "cuidado de si" aparece nos media corresponde, na verdade, a uma forte opacidade dos mecanismos de poder que se jogam no discurso jornalístico e nas representações populares que constroem uma dada visão ideológica da sociedade. Mas esses discursos e essas visões não podem ser entendidos como o simples produto dos recursos próprios que constituem o domínio da profissão jornalística. Do mesmo modo, não basta 
simplesmente avaliá-los em termos da sua correcção ou incorrecção face a um discurso prévio que lhes competia "transmitir". O discurso jornalístico concentra em si o espectro maior do espaço público, onde interagem actores, movimentos sociais, especialistas, leigos, com as suas experiências e visões do mundo. É nesse espaço que se jogam os direitos, a dignidade humana, as relações normativas e éticas que nos unem e, enfim, a nossa própria subjectividade.

As questões da fertilização e da genética em geral têm produzido um certo manancial de histórias nos nossos media. Mas poderemos afirmar que existe um espaço público em torno delas? Remoaldo e Machado (2006) referem como a questão da infertilidade ainda se mantém bastante invisível no nosso país, não havendo sequer dados certos sobre a sua extensão em Portugal. Onde estão as vozes das feministas, das mulheres? Qual o grau da sua inclusão? Quem tem, afinal, o poder de definir os temas para a sua compreensão pública? Do ponto de vista feminista, como podemos incluir nele os profundos dilemas que parecem atravessar, como vimos, as questões da reprodução assistida?

No espaço público os discursos diários são "fornecidos de oportunidades desiguais para exercer a influência" e são "infiltrados pelo poder administrativo e social e dominados pelos media" (Habermas, 1996, p. 364). Assim, as deliberações públicas diárias dos cidadãos (incluindo a dos próprios profissionais da saúde, como vimos) podem ser inibidas por condições e desvantagens estruturais da desigualdade que permitem que o dinheiro e o poder organizacional levem à manipulação da opinião pública, facilmente suprimindo ou impedindo a sua re-elaboração e influência no sistema político.

Por fim, há que recordar as palavras de Nancy Fraser: "Na sociedade em rede", diz, "a viragem feminista para o reconhecimento misturou-se de um modo demasiado confortável com um neoliberalismo hegemónico que nada mais quer do que reprimir a memória socialista" (Fraser, 2007, p. 24). Trabalhar pela justiça no espaço público, enfim, significa não apenas jogar nele os dilemas identitários que nos fragmentam, ignorando os aspectos materiais da desigualdade, mas identificar as desvantagens estruturais da desigualdade das mulheres que inibem o discurso público e as condições de verdadeira paridade que nos podem unir. Essa identificação é certamente uma das principais tarefas dos estudos feministas da comunicação. 


\section{BIBLIOGRAFIA}

AUGUSTO, A. "Os media e a construção social da infertilidade e da procriação medicamente assistida em Portugal". Actas do $\mathrm{V}^{\circ}$ Congresso Português de Sociologia, Sociedades Contemporâneas: Reflexividade e Acção, 2004.

AUGUSTO, A., "Infertilidade e Reprodução Medicamente Assistida: definição de contextos e produção de significados". In Carapinheiro G. (org.) Sociologia da Saúde: Estudos e Perspectivas. Porto: Editores Pé de Página, pp. 47-76, 2006.

BALSAMO, A., Technologies of the gendered body. Durham \& London: Duke University Press, 1996.

BUTLER, J., Bodies that Matter: On the Discursive Limits of "Sex". London: Routledge, 1993.

CARAPINHEIRO, G. (2006). "A saúde enquanto matéria política”. In Carapinheiro G. (org.) Sociologia da Saúde: Estudos e Perspectivas. Porto: Editores Pé de Página, pp. 137-164

CONCEIÇÃO, S., "A infertilidade no feminino". Actas do IV Congresso Português de Sociologia, edição de CD-ROM, 2002.

COREA, G., The Mother Machine: Reproductive Technologies from Artificial Insemination to Artificial Wombs. New York: Harper and Row Publishers, 1985.

DE BEAUVOIR, S., O segundo Sexo. Vol I - Os Factos e os Mitos. Amadora: Livraria Bertrand. 1975.

DENNY, E., "Liberation or oppression? Radical feminism and in-vitro fertilization". Sociology of Health and Illness. 16 (1): 62-80, 1994.

FERREE, M. M. AND GAMSON, W. A., "The Gendering of Governance and the Governance of Gender: Abortion Politics in Germany and the USA" in Barbara Hobson (ed.) Recognition Struggles and Social Movements. Contested Identities, Agency and Power. Cambridge: Cambridge University Press, pp. 35-63, 2003.

FLAX, J., "Postmodernism and Gender Relations in Feminist Theory. In: L. Nicholson (Ed.) Feminism/ Postmodernism. London: Routledge, 1990.

FOUCAULT, M., "História da Sexualidade I - A Vontade de Saber". Lisboa: Relógio D’Água, 1994.

FRANKLIN, S., "Deconstructing 'desperateness': the social construction of infertility in popular representations of new reproductive technologies". In M. McNeil, I. Varcoe and S. Yearley, eds, The New Reproductive Technologies. U.K: Macmillan. 1990.

FRANKLIN, S., "Postmodern Procreation: A Cultural Account of Assisted Reproduction". In F.D. Ginsburg and R. Rapp (eds) Conceiving the New World Order: The Global Politics of Reproduction. Berkeley: University of California Press, 1995.

FRANKLIN, S., Embodied Progress: A Cultural Account of Assisted Conception. London: Routledge, 1997. 
FRANKLIN, S., "Origin Stories Revisited: IVF as an anthropological project". Culture, Medicine and Psychiatry 30 (4): 547-555, 2006.

FRASER, N., "Rethinking the Public Sphere: A Contribution to the Critique of Actually Existing Democracy" in Craig Calhoun, ed. Habermas and the Public Sphere. Cambridge, MA: MIT Press, pp. 109-142, (1992).

FRASER, N., "From Redistribution to Recognition? Dilemmas of Justice in a 'Postsocialist' Age”, New Left Review, 212: 68 - 93, 1995.

FRASER, N. "Social Justice in the Age of Identity Politics". In N. Fraser and A. Honneth (eds) Redistribution or Recognition? London: Verso, 2003.

FRASER, N., "Feminist Politics in the Age of Recognition: A Two-Dimensional Approach to Gender Justice". Studies in Social Justice. 1(1): 23-35, 2007.

FRASER, N. e LINDA J. NICHOLSON, "Social Criticism Without Philosophy: An Encounter Between Feminism and Postmodernism." In Feminism/ Postmodernism ed. Linda J. Nicholson. New York: Routledge, pp. 19-38, 1990.

GIDDENS, A., Para Além da Esquerda e da Direita. Oeiras: Celta Editora, 1990.

GUERRINA, R., "Equality, Difference and Motherhood: the case for a feminist analysis of equal rights and maternity legislation". Journal of Gender Studies, 10 (1): 33 - 42, 2001.

HABERMAS, J., Between Facts and Norms. Contributions to a Discourse Theory of Law and Democracy. Cambridge, MA: MIT Press, 1996.

HARAWAY, D., "A manifesto for cyborgs: science, technology, and socialist feminism in the 1980s", in Linda J. Nicholson (Ed.). Feminism/ Postmodernism. New York: Routledge, pp. 190-233, 1990.

HODGETTS, D., \& CHAMBERLAIN, K. (2006). "Media and health: A continuing concern for health psychology". Journal of Health Psychology, 11 (2): 171-174.

HODGETTS, D., BOLAM, B., \& STEPHENS, S., "Mediation and the construction of contemporary understandings of health and lifestyle". Journal of Health Psychology, 10 (1): 125-138, 2005.

HODGETTS, D., \& CHAMBERLAIN, K., Narrativity and the mediation of health reform agendas". Sociology of Health and Illness, 25 (6): 553-570, 2003.

KLINE, K. N., "A Decade of Research on Health Content in the Media: The Focus on Health Challenges and Socio-cultural Context and Attendant Informational and Ideological Problems". Journal of Health Communication, 11:43-59, 2006.

LAM, CARLA, "Feminist Responses to the Disembodiment of New Reproductive Technologies and the Future of Feminism". CPSA Annual Conference, 2004.

Laqueur, T., Making Sex: Body and Gender from the Greeks to Freud. Cambridge. MA: Harvard University Press, 1990.

LEVY, T., "O Corpo à Superfície”. Revista Comunicação e Linguagens: Corpo, Técnica, Subjectividades, pp.83-104, 2004. 
LIE, M., "Science as father? Sex and gender in the age of reproductive technologies" European Journal of Women's Studies 9 (4): 381-399, 2002.

LUPTON, D., "Toward the Development of Critical Health Communication Praxis". Health Communication, 6 (1): 55-67, 1994a.

LUPTON, D., Medicine as Culture: Illness, Disease, and the Body in Western Societies, Thousand Oaks, CA: Sage, 1994b.

MACHADO, H. C. F., “'Vaca que anda no monte não tem boi certo': uma análise da prática judicial de normalização do comportamento sexual e procriativo da mulher". Revista Crítica de Ciências Sociais, N. ${ }^{\circ}$ 55: 167-184, 1999.

MAESEELE, P. A. (2007). "Science and technology in a mediatized and democratized society". Journal of Science Communication, 6 (1): 1-10.

MARTIN, E., "The Egg and the Sperm. How Science has Constructed a Romance Based on Stereotypical Male-Female Roles". Signs 16(3): 485-501, 1991.

NELKIN, D., Selling Science: How the Press Covers Science and Technology. New York: W. H. Freeman, 1987.

O'BRIEN, M., "The politics of hysteria: man, media, and the test-tube baby", Canadian Women's Studies, Summer 1979,

PETERSEN, A. \& LUPTON, D., The New Public Health: Health and Self in the Age of Risk. Allen \& Unwin, Sydney, 1996.

PHILLIPS, A., "Introduction" in A. Phillips (Ed.) Feminism and Equality. Oxford: Basil Blackwell, 1987.

PONTE, C., "O nascimento de Adam Nash. Análise comparada de uma notícia de genética em seis jornais de informação geral", Media \& Jornalismo, 1 (1): 65-79. 2002.

REMOALDO, P. C.; MACHADO, H. C., "Reproductive health as a gendered indicator of well-being: the case of "infertility"'. Symposium Well-being as a Social Gendered Process University of Modena, Italy, 2006.

RICH, A., Of Woman Born. Motherhood as Experience and Institution. New York: Norton and Company, 1976.

ROBERTS, C., Messengers of Sex: hormones, biomedicine and feminism. Cambridge University Press, 2007.

ROWLAND, R., Living Laboratories: Women and Reproductive Tecnology. UK: Lime Tree, 1992.

SAWICKI, J., Disciplining Foucault: Feminism, Power and the Body. New York: Routledge, 1991.

SCAMBLER, G., "The 'project of modernity' and the parameters for a critical sociology: an argument will illustrations from medical sociology". Sociology, $30,567-581,1996$.

SCAMBLER, G., Habermas, Critical Theory and Health. London: Routledge. 2001.

SEALE, C. F., Media and Health. London: Sage Spallone, P. (1989). Beyond Conception: The New Politics of Reproduction. UK: MacMillan Education. 
SPILKER, K. and M. LIE., "Gender and Bioethics Intertwined. Egg Donation within the Context of Equal Opportunities". European Journal of Women's Studies, 14 (4): 327-340, 2007.

STEVENSON, F., SCAMBLER, G., "The relationship between medicine and the public: the challenge of concordance". Health (London) 9: 5-21, 2005.

THROSBY, K., When IVF fails: Feminism, infertility and the negotiation of normality, Basingstoke: Palgrave Macmillan, 2004.

TURNER, B. S., The Body \& Society: Explorations in Social Theory. London: Sage. Van Dyck, J. (1995). Manufacturing Babies and Public Consent, Debating the New Reproductive Technologies, New York University Press, 1996.

WALLACK, L., "The role of mass media in creating social capital: A new direction for public health". in Brian D. Smedley and S. Leonard Syme (Ed.). Promoting Health: Intervention Strategies from Social and Behavioral Research. The National Academies Press, pp. 337-365, 2003. 